of the Romans on such sites. "You must deal with barbarians spiritually as well as physically," he says, "and convey to them that your civilization has qualities which they can envy and emulate, as well as wealth they can loot." Contrast the survival value of Greece. The Greeks absorbed foreign blood without losing their Greek character ; and their invention, the polis, had not only a prodigious attraction as a mode of life to bar. barians of all kinds, but also it carried Hellenism from Greece to the Indus. The Greeks saw that you must present to a people of a lower order of development something which will attract them to you, not with the desire to take your surplus wealth, but to emulate your mode of life.

"Such reflections," concludes Mr. Casson, "on the breaks and pauses in the course of civilization have some value for those who argue by analogy. . . We should pocket our pride and glance at some of our past failures. For they are chastening to those who indulge in that greatest weakness of the civilized-complacency."

\title{
INSECTS IN THE UPPER AIR
}

\author{
By DR. A. D. Imms, F.R.S.
}

$\mathrm{T}^{\mathrm{H}}$ HE investigation of insects in the upper air has so far been conducted on a very limited scale. Probably the first attempt to collect insects from such an environment was that made by E. P. Felt, in the United States in 1926, who used a special kind of trap attached to the lower wings of an aeroplane. Since that year, several experimental attempts have been made to explore the insects and other arthropods of the upper air. Thus in 1931, 1932 and 1933 more extended flights by aeroplanes, with insect traps attached, were made in the United States.

The first European entomologist to attempt this line of investigation was L. Berland who, in 1934, used an aeroplane with specially devised nets attached to the wings and controlled from the cockpit. Many flights were made and all were in the vicinity of Paris. Very similar methods have also been used in Asia Minor and at Oran in Algeria. In 1937, J. A. Freeman made collections of insects in the upper air by using kites along the Great Lakes in Canada.

Between 1932 and 1935 Freeman, working in England in conjunction with A. C. Hardy, made a study of insect drift, using nets attached to $300 \mathrm{ft}$. masts of a wireless station. Specially constructed kites enabling samples to be obtained from given altitudes were also used. In 1938, A. C. Hardy and R. S. Milne published a detailed account of aerial tow-netting from kites with closeable nets attached.

The most extensive investigation of insects in the upper air is that described by P. A. Glick in Technical Bulletin No. 673 (May, 1939) of the U.S. Department of Agriculture. Under the title of "The Distribution of Insects, Spiders and Mites in the Air", a detailed account of the work, running to 150 pages, is given. The collecting was done during the five-year period 1926-1931, and special kinds of trap fitted to the wings of diverse types of aeroplane were employed. It appears that more than 1,300 flights were made at Tallulah (La.) and 44 flights in Mexico. More than 30,000 insects and spiders were taken at altitudes ranging from $20 \mathrm{ft}$. to $15,000 \mathrm{ft}$. and were most abundantly captured in the month of May. Eighteen orders of insects together with arachnids were represented. In the Tallulah collections there were more than 700 species belonging to more than 200 families. The order Diptera was the most abundant and was represented by nearly three times as many specimens as in any other order: Coleoptera followed next as regards numbers taken.

The highest altitude at which insects were captured was 14,000 feet and, as a general rule, their frequency of capture was in inverse ratio to the altitude. Among individual orders of insects, only 21 specimens of dragonflies were collected, and the author states that this is due to their rapid flight and their ability to avoid the on. coming aeroplane. He records having observed Odonata (probably Anax junius) keeping up with, and sometimes even flying ahead of, an aeroplane that was travelling at 90 miles or more per hour. Homoptera were captured at almost every altitude up to 14,000 feet. More than half of the Coleoptera taken belonged to the families Carabidx, Staphylinidæ, Chrysomelidæ and Curculionidæ or, in other words, to the largest groups of these insects. Altogether 4,420 specimens belonging to 191 genera of Coleoptera were captured in the traps and the maximum elevation was $11,000 \mathrm{ft}$. Lepidoptera (32 species) were not captured higher than $5,000 \mathrm{ft}$. Hymenoptera, represented by nearly 250 genera, were obtained at nearly all elevations up to $14,000 \mathrm{ft}$. Their dominant representatives 
belonged to the Parasitica and the ants. Of the Diptera the most abundant families represented were the Chloropida with 2,227 specimens and the Chironomidæ with 701 examples. Culicidæ were represented by 111 specimens belonging to seven genera.

Among apterous forms, 1,461 spiders were captured, one example occurring at $15,000 \mathrm{ft}$. A single example of Pulex irritans at $200 \mathrm{ft}$. is recorded. Numerous Apterygota are mentioned, besides wingless Hymenoptera, etc., and larvæ.

Among the various factors governing the distribution of insects in the upper air the size, weight and buoyancy of individual forms are discussed together with the influence of temperature, dewpoint, barometric pressure, wind direction and velocity, convection, light intensity, etc. Of these, and other factors, temperature is regarded as the most important agency regulating the numbers of insects to be found in the air at any given time.

With the great number of acroplanes now in regular use in the world, numerous ways are offered for insects to find shelter in these vehicles and so become carried from one territory to another. New means for the dispersal of dangerous insect pests are thus afforded. Air currents are also believed to be an important accessory factor in the distribution of the destructive pink bollworm in the United States. During the five years of flying to collect insects, many kinds of these creatures were found either in the cockpit, fuselage or cabin of the planes used, but no special collections were made.

\section{OBITUARIES}

General the Hon. C. G. Bruce, C.B.

$\mathrm{B}$ RIGADIER-GENERAL THE HON. C. G. BRUCE died on July 12 at the age of seventythree years.

Charles Granville Bruce, born in 1866, was a son of the first Lord Aberdare. Probably no man since the time of the Schlagintweits had a wider knowledge of the Himalaya than Bruce. No one ever had so intimate a knowledge of so many of its peoples. Bruce's climbing experience extended from the Safed Koh to Sikhim. He was with Conway in his notable expedition to the Karakorum, and with Mummery and Collie in the first attempt on Nanga Parbat. The snows of Khagan and Kulu were his happy hunting grounds. In 1907, the jubilee year of the Alpine Club, he nearly arranged the first exploration of Nount Everest; but at the last moment the plan was vetoed in London by John Morley, who feared Russian suspicion. Again in 1910 he got leave from the late Maharaja to explore Everest from the Nepalese side; but at the last moment this had to be given up for fear of arousing religious hostility.

By profession a soldier, Bruce was an acknowledged master in the difficult technique of fighting on the North-West Frontier. His influence with his own Gurkhas was remarkable, and his greatest contribution to mountaineering came through his wide knowledge of the tribes of the Himalaya. He was the first to use trained Gurkhas for serious mountain work. He started the Baltis of Kashmir and the Bhotias of Garhwal on the upward path, a lead which Kellas ably followed. But his great discovery was the value of the Sherpa, a Tibetan tribe long settled in Nepal. These, with their purer Tibetan cousins, have been the mainstay of every Himalayan expedition of recent years. The cause of his success was his sympathy with and knowledge of the languages and habits of these very varied peoples.

In 1923 Bruce was elected president of the Alpine Club. In 1915 he was awarded the Gill Memorial Prize and in 1925 the Founder's Medal of the Royal Geographical Society. But it was the adventure, not scientific interests, which absorbed him during his climbing holidays and longer oxpeditions. Of the latter, the Everest expedition of 1922 stands out. He made an ideal leader. Yet it is as a companion, the perfect ono, that I most remember him, especially with Arnold Mrumm and myself in Garhwal in 1907. He was the most invariably considerate, and pleasant, and uncomplaining companion it is possible to imagine. Not even the injured knee which deprived him of climbing Trisul with his devoted Subadar Khàrbir Burathoki drew one word of disappointment or complaint from him. Bruce's name became a household word : but only his friends knew his real worth. T. G. LongstafF.

\section{Prof. Archibald Young}

Prof. Archibald Young, who died in Glasgow on July 24 at the age of sixty-five years, had held the regius professorship of surgery in the University of Glasgow since 1924, when he succeeded Sir Williarn Macewen: He had come under the influence of his predecessor, and this partly accounted for his leaning towards the surgery of the nervous system, to which he had regularly contributed since his service in the South African War. MIoreover, this choice of speciality was natural in one whose clinical inclinations were coloured by the minutest examinations of clinical cases.

Prof. Young was at his best in dealing with 